\title{
A conquista de Alandalus segundo o relato de 'Abdulmalik Bin Ḥabīb (m. 238 H./853 d.C.)
}

Mamede Jarouche*

\section{RESUMO}

O presente trabalho consiste numa tradução anotada, precedida de uma nota explicativa, do capítulo relativo à conquista da Península Ibérica pelos muçulmanos no livro Kitāb Attārīh (“Livro de História”), de Ibn Habīb, historiador árabe andaluz do século IX. Trata-se do primeiro livro de história escrito por um árabe daquela região e a crônica a respeito da sua conquista pelos muçulmanos é, ao lado de outra crônica que durante algum tempo foi equivocadamente atribuída a Ibn Qutayba, também do século IX, a mais antiga que chegou até os dias de hoje. As notas limitam-se à tentativa de esclarecer eventuais obscuridades do original e dar informaçóes sobre personagens e fatos históricos que, supôs-se, não ficariam claros para o leitor brasileiro.

Palavras-chave: História islâmica; Andaluzia muçulmana; Conquistas muçulmanas; Idade Média; Historiografia Islâmica.

\section{ABSTRACT}

This work consists of an annotated translation, preceded by an explanatory note on the chapter concerning the Muslim conquest of the Iberian Peninsula in the book Kitāb Attārīh ("Book of History"), by Ibn Habib, an Andalusian Arab historian of the nineth century. This is the first history book written by an Arab in that region, and his narrative is, alongside another one, which was mistakenly attributed to Ibn Qutayba for some time, also from the nineth century, is the oldest surviving narrative on the conquest of Andalusia. The notes are limited to clarifying any obscurities of the original text, and to providing information on characters and facts that might not be familiar to the Brazilian reader.

Keywords: Islamic History; Muslim Andalusia; Muslim Conquests; Middle Ages; Islamic Historiography.

DOI - http://dx.doi.org/10.1590/2237-101X01803501

Documento recebido em 29 de abril de 2017 e aprovado para publicação em 7 de maio de 2017.

*Professor da Universidade de São Paulo, São Paulo - SP, Brasil. E-mail: jarouche@usp.br. 
Mamede Jarouche

\section{RESUMEN}

Este trabajo consiste de una traducción anotada, precedida por una nota explanadora sobre el capitulo que se refiere a la conquista islámica de la Península Ibérica en el libro Kitāb Attārīh ("Libro de Historia”), de Ibn Habīb, historiador árabe andaluz del siglo IX. Se trata del primer libro de historia escrito por un árabe de la región y la crónica sobre su conquista es una de las dos más antiguas conocidas — la otra, también del siglo IX, ha sido por algún tiempo atribuida a Ibn Qutayba. Las notas se limitan a aclarar eventuales obscuridades del original y a dar informaciones sobre personajes y hechos históricos que, se supone, no serian conocidos del lector brasileño.

Palabras clave: Historia islámica; Andalucía musulmana; conquistas musulmanas; Edad Media; historiografía islámica.

'Abdulmalik Bin Ḥabīb Bin Sulaymān Bin Hārūn (ou Marwān) Bin Julhuma (ou Jāhima) Bin 'Abbās Bin Mirdās Assulamī, ${ }^{1}$ nascido em Elvira ou Córdoba por volta de 790 e morto em 852 ou 853 d.C., foi, ao menos de acordo com os registros hoje disponíveis, o primeiro letrado andalusī a compor um livro de história, o Kitäb Attārīh o qual contém um capítulo inteiramente dedicado à conquista de Alandalus, a saber, a porção da Península Ibérica ocupada pelos muçulmanos em $711 .^{2}$ Trata-se, portanto, de um dos mais antigos relatos sobre tal conquista, se não o mais antigo. $\mathrm{O}$ arabista espanhol J. Aguadé registra que se trata da "única história universal escrita em Alandalus que chegou aos nossos dias". De fato, as outras histórias por lá escritas, como as mais conhecidas de Ibn Alqūṭiyya, de Ibn Ḥayyān, de Ibn Alḩațīb, além da muito citada compilação anônima Ahbār Majmū'a (Crônicas reunidas), entre tantas outras, são relativas às coisas da própria Alandalus. É bem possível que os letrados locais tenham se bastado com as histórias universais escritas pelos árabes do Oriente, ${ }^{3}$ ainda que, pouco mais de um século após a morte de 'Abdulmalik Bin Habīb, tenha chegado a Alandalus, via Bizâncio, uma "história universal", Historiarum Contra Paganos, do galego Paulus Orosius (séc. IV-V d.C.), logo traduzida ao árabe para o califa

\footnotetext{
${ }^{1}$ Todos os dados a respeito do autor foram extraídos da introdução escrita por Jorge Aguadé à sua excelente edição do texto árabe (cf. adiante a referência completa à edição).

${ }^{2}$ Conforme já se explicou em outros trabalhos por nós traduzidos, consideramos o termo Alandalus, cunhado pelo arabista espanhol F. Corriente, preferível a Andaluzia. Como se sabe, Alandalus era a palavra usada pelos árabes para referir qualquer parte da atual Península Ibérica, ao passo que Andaluzia, embora evidentemente derive da primeira, se refere apenas e táo somente a uma regiáo do sul da Espanha.

${ }^{3}$ Como a volumosa Tārīh Arrusul wa Almulūk (História dos profetas e dos reis), de Muhammad Bin Jarīr Atțabarī (m. 923 d.C.), historiador nascido no Tabaristão, completada pelo letrado cordobês 'Arīb Bin Sa d, morto na segunda metade do século X. O fato de ter surgido a necessidade de completá-la evidencia que circulava amplamente entre letrados locais.
} 
cordobês Alḥakam (914-976 d.C.), segundo ambíguas informaçóes de Ibn Ḩaldūn, pelo juiz e pelo turgimão dos cristáos de Córdoba.

Ibn Ḥabīb - não exatamente um letrado notável, pois rapidamente a memória de seus escritos e ditos esmaeceu e se dispersou - era um alfaqui, isto é, doutor da lei religiosa em sentido estrito, conforme se evidencia pela produçáo a ele atribuída, toda ligada, direta ou indiretamente, a questốes desse âmbito. Nesse sentido, mesmo um trabalho como o Livro de história, em princípio pertencente a outro campo, é sobredeterminado pela concepção teleológica daí derivada. Por isso, o capítulo adiante traduzido não pode, obviamente, ser lido como uma narrativa moderna na qual se arrolam apenas e tão somente "fatos concretos": conquanto os contenha também, o verossímil de sua narrativa, ou por outra, a sua coerência está embasada na escatologia muçulmana, que pensa, ou pensava, o tempo como ciclos que se repetem; ademais, está presente também a ideia do final do mundo, do apocalipse, com a obsessão pelos sinais que o indicarão, o que quase naturalmente leva à introdução de vaticínios, hiperinvestidos de sentido e por consequência abertos à hiperinterpretação, o que, de modo inevitável, os torna obscuros e enigmáticos, como observa com agudez J. Aguadé. Contudo, esse peculiar modo de produção do discurso histórico decepcionou — sempre conforme Aguadé, que neste ponto secunda seu mestre, o grande crítico egípcio Maḥmūd 'Alī Makkī — o positivismo de orientalistas como o holandês R. Dozy, ou de historiadores como o espanhol Sanchez Albornoz, os quais, não encontrando no livro de Ibn Habīb o que desejavam (isto é, elementos que corroborassem a teleologia deles), puseram-se a desclassificá-lo e atribuí-lo a outros autores. Seria de se lamentar tamanho anacronismo, não fosse Dozy, estimável lexicógrafo e filólogo, uma ridícula negação em tudo o mais, e Sanchez Albornoz um anacronizador contumaz de quem, ao menos no que tange à história de Alandalus, não se deve esperar grande coisa. ${ }^{4}$

Aguadé e Makkī observam, igualmente, que em seu estado atual o livro é fruto da recompilação de um certo discípulo seu, Almagaāmī, que em algumas de suas passagens se refere a Ibn Ḥabïb em terceira pessoa, com formulaçôes como "Perguntei a 'Abdulmalik" ou "Perguntei-lhe" etc. São dessa personagem obscura as interpolaçóes e intervençôes, realizadas entre o final do século IX e o início do X, que procuram "atualizar" o livro acrescentando-lhe fatos e informaçóes de períodos posteriores à morte do autor - prática habitual, diga-se de passagem, e observável em diversas obras árabes.

A tradução que se lerá a seguir foi feita a partir da edição publicada por Jorge Aguadé, 5 conforme se disse, baseada no único manuscrito existente da obra, conservado na Biblioteca

\footnotetext{
${ }^{4}$ Sobre a historiografia da invasão muçulmana, cf. SANJUÁN, Alejandro García. La Conquista Islámica de la Peninsula Ibérica y la Tergiversación del Pasado. Madri: Marcial Pons, 2013.

${ }^{5}$ Edição publicada em 1991 pelo Consejo Superior de Investigaciones Científicas do Instituto de Cooperación con el Mundo Árabe, Madri. Trata-se do primeiro volume de uma preciosa coleção, Fuentes Arábico-Hispanas. Existe outra edição desse livro publicada no Líbano pela editora Almaktaba Al'așriyya, "sob os cuidados" de 'Abdulġanī Mustū, cuidados esses que não foram além de copiar — sem citar, como de hábito — a edição de Aguadé, corrigindo um ou outro erro de revisão, escrever-lhe uma curta introdução e aduzir-lhe algumas notas óbvias. O trecho sobre Alandalus, de acordo com Aguadé, já fora editado pelo pranteado Maḥmūd 'Alī Makkī, porém o tradutor não pôde ter acesso a esse trabalho.
} 
Bodleiana de Oxford, e datado de 1295-96 d.C. Acompanhando o texto árabe, Aguadé escreveu em espanhol uma substanciosa introdução às questôes suscitadas pela obra e por seu autor, incluindo igualmente a sua tradução de algumas passagens. A presente tradução, insista-se, não tem outro propósito que não o de tornar acessível em português o teor desse texto, o qual, como se ressaltou, é um dos primeiros relatos sobre a conquista árabe-muçulmana de Alandalus. Os números que antecedem muitos parágrafos correspondem aos números constantes da edição de Aguadé, e foram mantidos para facilitar eventuais comparaçôes e checagens. Ao contrário do que se fez em nossa tradução da crônica do pseudo Ibn Qutayba, constante da obra coletiva Diálogo das civilizaçôes: cultura e passagens, organizada por Olgária Matos, Denise Milan e Javier Amadeo e publicada em 2017 pela editora da Unifesp, no presente trabalho os nomes de personagens e lugares foram aportuguesados, na medida do possível.

\section{Capítulo da conquista de Alandalus}

(394) Disse 'Abdulmalik Bin Ḥabïb:

Ibn Wahb conversou conosco e nos disse:

Mūsà Bin Nuṣayr enviou o seu servo Ṭāriq para Tlemcen e lhe ordenou que se encarregasse de sua costa e de seus portos, mantendo-os sob vigilância para assim, quem sabe, capturar os navios dos rümis e encontrar em meio a eles um ancião dotado de saber. ${ }^{6}$ Tāariq assim procedeu, encontrou o anciáo e lhe perguntou: "Acaso sabes quem irá conquistar Alandalus?". O velho respondeu: "Ela será conquistada por vós, juntamente com um povo ao qual se dá o nome de berberes, que são da vossa religião". Então Ṭāriq escreveu a respeito para Mūsà Bin Nuṣayr, que convocou os berberes e deles lhe enviou mil homens. Mūsà, que era um dos mais entendidos em astrologia, escreveu a Țāriq: "Vais chegar a um rochedo na costa; então atraca ali os teus navios e procura, entre os teus homens, um que conheça os nomes dos meses em siríaco. Quando for o dia vinte e um do mês de ayyār, que nos cálculos estrangeiros é maio, ousa, com a bênção e a ajuda de Deus, e avança, com o apoio e auxílio dele, até topares com uma pequena montanha vermelha em cuja base haverá uma fonte oriental e a seu lado a estátua de um ídolo em forma de touro; quebra a estátua e dirige-te a um homem alto, loiro, com estrabismo nos olhos e paralisia nas mãos, e coloca-o na tua vanguarda". Quando a carta chegou a Țāriq, ele respondeu a Mūsà Bin Nuṣayr: "Executarei o que determinaste. Quanto às características do homem a respeito do qual me deste ordens, não as encontrei em ninguém, salvo em mim mesmo".

\footnotetext{
${ }^{6}$ No caso, trata-se de capacidade de fazer prediçôes, quase um análogo do vaticínio.
} 
(395) Em seguida, Taāriq avançou com mil e setecentos homens. Porém, os soldados berberes, na quantidade de doze mil, entre eles dezesseis árabes, não se reuniram a ele senão após a conquista, de modo que Ṭāriq avançou com os seus mil e setecentos homens no mês de rajab do ano de noventa e dois da Hégira.

(396) Ao tempo da chegada de Ṭāriq, o rei de Alandalus realizava uma expedição contra um seu inimigo e deixara no trono um de seus reis, chamado Tudmīr, a quem entáo estava submetida toda a [região de] Tudmīr, que por isso recebera o seu nome e fora a ele relacionada. ${ }^{7}$ Quando Tudmīr recebeu a notícia da chegada de Ṭāriq e dos muçulmanos que com ele estavam, escreveu a Luḍīq, então rei de Alandalus: "Chegaram à nossa terra umas gentes que não sabemos se desceram do céu ou se brotaram do chão”. Ao receber tal notícia, Lud rīq voltou [para combater] Ṭāriq com setenta mil peóes e carros transportando dinheiro e joias, ele sentado em seu trono, entre duas bestas e com uma cúpula cravejada de pérolas, rubis e esmeraldas, e com montarias carregando cordas, pois ele não tinha dúvidas de que os aprisionaria.

Quando Ṭāriq foi informado da sua aproximação, levantou-se entre os seus companheiros, louvou a Deus, exalçou-o, incitou-os à luta, fê-los desejar o martírio e disse: "Ó gente! Onde a saída? O mar está às vossas costas, o inimigo à vossa frente. Por Deus que não vos resta, portanto, senão a retidão e a perseverança. Por acaso não vou enfrentar em pessoa o tirano deles? Não me deterei até atingi-lo ou então ser morto antes de chegar a ele”.

(397) Luḍīq era de Ispahan, que em Alandalus é chamada de Išbān, ${ }^{8}$ que são os godos, reis bárbaros de Alandalus. Țāriq avançou até Luḍrīq, e Luḍīq até Ṭāriq, e eles travaram combate renhido. Depois o tirano Luḍrīq teve o exército inteiramente derrotado, e os muçulmanos obtiveram ouro, prata e joias em quantidades tais que não se contavam e cujo valor não se calculava. As pessoas saquearam naquele dia e embarcaram em direção a Tânger. Quando estavam no meio do mar ouviram alguém gritando: "Afunda-os, pois praticaram o saque", e então acorreram aos exemplares do Alcorão, penduraram-nos nos pescoços, rogaram a Deus altíssimo e poderoso e lhe suplicaram. Logo alguém gritou, o barco virou com eles e ninguém se salvou, exceto aqueles que Deus quis que se salvassem.

(398) Depois, Mūsà Bin Nuṣayr saiu no mês de rajab para tomar Alandalus de seu servo Tāariq, pois estava extremamente encolerizado com ele. Avançou até Alandalus com dez mil homens. Țāriq o recebeu e o apaziguou, e Mūsà se apazigou e lhe aceitou as desculpas.

\footnotetext{
${ }^{7}$ Segundo o geógrafo e biógrafo medieval Yāqūt (m. 1228 d.C.), esse rico distrito, situado a leste de Córdoba, "a sete dias de cavalgada", situava-se depois da região agrícola do distrito de Jaén (Mư jam Albuldān, [Dicionário de países], Beirute: Șādir, 1977, v. II, p. 19).

${ }^{8}$ Essa curiosa referência a Rodrigo, último rei visigodo, era bastante espalhada entre os antigos historiadores árabes. J. Aguadé remete, entre outros, ao historiador oriental Ibn Alatīir (1160-1232 d.C.), o qual, no seu volumoso e célebre Alkāmil fì Attārīh, (O [livro] perfeito em história), dá detalhes sobre essa crença, bem como sobre a origem da denominação Išbān (compare com "Espanha"), ligando-a a Tịṭus Bin Išbān — Tito, imperador romano (Alkāmil fì Attārīh, Beirute: Șādir, s/d, v. IV, p. 556 e ss.).
} 


\section{Mençáo dos membros da geração dos seguidores dos companheiros do profeta9 que entraram em Alandalus}

(399) O número dos seguidores dos companheiros do profeta que entrou em Alandalus, salvo os desconhecidos, foi de vinte homens: foi com eles que Mūsà chegou a Ifrīqya. $\mathrm{O}$ nascimento de Mūsà Bin Nuṣayr Bin 'Abdurraḥmān Bin Zayd deu-se no ano de dezenove da Hégira, durante o califado de 'Umar Bin Alhatțāb, que Deus esteja satisfeito com ele.

O califa Mu'āwya Bin Abī Sufyān nomeou Nuṣayr, pai de Mūsà, chefe de sua guarda, mas, como ele não combatesse ao seu lado, Mu'āwya lhe disse: "O que te impediu de enfrentar 'Alī comigo? Não me devias favores?". Ele respondeu: "Não me seria possível agradecer-te blasfemando contra quem é mais digno do meu agradecimento do que tu". Perguntou o califa: "Quem?". Respondeu: "Deus poderoso e exalçado". Perguntou o califa: "Como é isso, ó desalmado?". ${ }^{10}$ Ele respondeu: "Como não te dizer isso? Do contrário, eu me desgostaria e sofreria”. ${ }^{11}$ Então Mu'āwya abaixou a cabeça por um bom tempo e depois disse: "Que Deus perdoe", e aceitou a desculpa de Nuṣayr.

(400) E Mu'āwya costumava dizer num provérbio que aplicava: "Uma espadeirada tomada com honra me é preferível a uma chicotada tomada com humilhação". E esse provérbio é o espanto dos espantos [aplicado] por alguém voltado para as coisas mundanas, mas não por alguém voltado para a outra vida, pois para este último uma espadeirada recebida por obedecer a Deus é mais prazerosa e saborosa que uma chicotada recebida por desobedecer a Deus. ${ }^{12}$ Disse certo homem sapiente:
A honra não é senão a obediência a Deus, apenas;
Ele é a base, a fortaleza inexpugnável e poderosa,
E a obediência a ele é honra, é refúgio e é pujança,
E quem lhe desobedece náo deve ambicionar a honra.

(401) Disse Allayt Bin Sa d:

\footnotetext{
9 "Geração dos seguidores dos companheiros do profeta" traduz o termo tābi ūin, literalmente "seguidores"; nesse caso, os seguidores dos companheiros do profeta, isto é, homens que receberam o seu aprendizado diretamente deles.

10 "Ó desalmado" traduz lā umma laka, isto é, "não tenhas mãe", ou "sem mãe".

11 "Do contrário, eu me desgostaria e sofreria" traduz fa-ag่uḍ wa amuḍd. Em Ibn Huillikān, historiador do século XIII, que transcreve o diálogo em seu livro de biografias Wafayāt Alàyān wa Anbä'Abnä' Azzamān (Os óbitos dos dignitários e notícias dos homens ilustres), esse trecho é fa-a udd wa amuṣs, "ou entáo eu morderia e chuparia" (ed. de I. 'Abbās, Beirute: Șādir, s/d, v. V, p. 319).

${ }^{12}$ Entenda-se: Mu'āwya Ibn Abī Sufyān (m. 680 d.C.), primeiro califa omíada e fundador dessa dinastia, é comumente visto pelos letrados muçulmanos como um oportunista, por haver se oposto e, na opiniáo de muitos, espoliado o poder do entáo califa, o quarto - e último - dentre os chamados rāšidūn (algo como "bem guiados"), 'Alī Ibn Abī Ṭālib, primo do profeta.
} 
Quando Mūsà Bin Nuṣayr chegou a Ifrīqya com um grupo de pessoas, antes de conquistar Alandalus, enviou para aqueles lados um filho seu chamado 'Abdullāh, que de lá lhe trouxe cem mil prisioneiros; depois, dirigiu-se ele mesmo a outro dos lados de Alandalus e de lá trouxe mais cem mil prisioneiros; assim, o montante dos impostos ${ }^{13}$ então recolhidos foi de cinquenta mil prisioneiros.

Prosseguiu Allayt:

Nunca se ouviu, no islã, sobre quantidade igual de cativos como os de Mūsà.

(402) Disse Abū Šìba Așṣudafĩ:

Marwān Bin Mūsà Bin Nuṣayr veio do extremo de Sūs arrastando enorme quantidade de cativos. Quando o seu emissário chegou até Mūsà, este saiu para recepcionar o filho acompanhado de muita gente notável; ao se encontrarem, Marwān Bin Mūsà disse: "Mandai que seja entregue uma jovem escrava a todo aquele que vier me receber ao lado do meu pai, a um por um”. Dada tal ordem, Mūsà ouviu enorme algazarra e gritaria, viu muita movimentação e perguntou: "O que está acontecendo?". Responderam: “Teu filho Marwān ordenou que dessem às pessoas uma jovem e bela pajem”. Mūsà redarguiu: "Ordenai que lhes deem de minha parte, a um por um, um jovem e belo pajem". E quando saíram dali, todos estavam com um pajem e uma pajem.

Menção do ouro, da prata, das esmeraldas, dos rubis, dos topázios e de outras coisas só por Deus conhecidas que Mūsà Bin Nuṣayr encontrou na cidade de Toledo no dia em que a conquistou

(403) 'Abdullāh Bin Wahb nos contou, a partir do que foi contado por Allayt Bin Sa d, que, quando conquistou Alandalus, Mūsà Bin Nuṣayr avançou rumo a seu destino, conquistando cidades à direita e à esquerda, até chegar a Toledo, cidade dos reis, na qual encontrou uma casa chamada "Casa dos Reis"; abrindo-a, nela encontrou vinte e cinco coroas cravejadas de pérolas e rubis, e essas coroas eram no mesmo número dos reis que governaram Alandalus: a cada vez que um deles morria, sua coroa era ali depositada, nela se gravando o seu nome, a que idade chegara na data de sua morte e quantos anos permanecera como rei. Diz-se que o número de governadores muçulmanos de Alandalus, desde a sua conquista até o dia em que será arruinada, será o mesmo número dos reis não árabes ${ }^{14}$ que a governaram, ou seja, vinte e cinco reis.

(404) Ao lado desta casa na qual estavam as coroas havia outra casa com vinte e quatro cadeados: a cada vez que um rei era empossado, nela se colocava um cadeado; tal foi o proce-

\footnotetext{
13 "Imposto" traduz hums, espécie de tributo que significa "quinto". Pela imprecisão, traduziu-se apenas como "imposto".

14 "Não árabes" traduz al ajam, palavra que pode ter vários sentidos: estrangeiro, bárbaro, persa etc.
} 
dimento dos reis anteriores, até que reinou Luḍīq, sob cujo governo Alandalus foi conquistada pelos muçulmanos. Poucos dias antes dessa conquista, Lud̂rīq dissera: "Por Deus que não morrerei aflito por causa dessa casa; é imperioso que eu a abra para saber o que há dentro dela". Então os cristãos, seus diáconos e seus bispos se reuniram e lhe disseram: "O que pretendes abrindo essa casa? Reflete sobre o que supóes que ela contenha, e aquilo por que o teu coração anela, e leva-o de nós, mas não nos causes algo jamais causado por nenhum dos reis que te precederam, e que eram gente de conhecimento e saber em tudo quanto fizeram". Mas, em virtude do destino predeterminado, ${ }^{15}$ ele se recusou e insistiu em abrir a casa, nela encontrando um ataúde de madeira em cujo interior havia gravuras dos árabes e seus tipos, de turbante, com arcos árabes e portando espadas cortantes; também encontraram na casa um escrito no qual se lia: "Se esta casa for aberta e nela se entrar, esses cujas características e descrição são essas entrarão neste país, reinarão sobre ele e serão vencedores”. E a entrada dos muçulmanos se deu naquele mesmo ano.

Mūsà ordenara que se fincassem estacas para o seu cavalo sob a parede da casa, mas, a despeito dos golpes, as estacas não penetraram, pois havia lâminas de ouro e prata enterradas no entorno da casa.

(405) Disse Abū Šìba Aș̣̦adafī:

Olhei para dois homens que carregavam um tapete tecido a ouro, prata, pérolas e rubis; quando ele se lhes tornou pesado, colocaram-no no chão e o cortaram com um machado em duas partes, levando uma metade e largando a outra. Também vi os homens passando por essa metade abandonada sem lhe darem atençáo, ocupados que estavam com o que levavam nas mãos, e que era mais valioso do que essa metade de tapete.

\section{Descrição da mesa de Salomão, Deus o bendiga e salve, bem como ao nosso profeta}

(406) 'Abdullāh Bin Wahb nos contou, a partir do relato de Allayt Bin Sa'd, que, ao conquistar Toledo, Țāriq, servo de Mūsà Bin Nuṣayr, ali encontrou a mesa de Salomão, filho de David, a paz seja sobre ambos, cravejada de gemas bordadas a ouro e ornada com pérolas e rubis cujo valor ninguém conhecia, além de uma outra mesa de mármore, de valor também incalculável.

(407) 'Abdulhamīd disse:

Perguntei sobre as características da mesa a meu pai, que a vira e contemplara. Ele respondeu: "Era de ouro e prata misturados, adquirindo a cor amarela do ouro e a branca da prata; havia sobre ela um colar de pérolas, um colar de rubis e um colar de esmeraldas". Perguntei: "Qual era a sua grandeza?". Ele respondeu: "Foi transportada sobre um asno, dos

15 "Destino predeterminado" traduz alqadar almuqaddar. 
mais potentes que podem existir, e ele avançou com a mesa por um trecho e então suas patas se dobraram".

(408) Disse 'Abdulhamìd:

Depois Mūsà saiu de Toledo com suas legiôes em ataque, conquistando cidades, e vieram ter com ele nobres do povo de Galiza pedindo-lhe paz. Ele fez a paz e atacou os bascos, aprofundando-se em sua terra até topar com um povo desnudo como bestas; ${ }^{16}$ em seguida, fez a curva para a terra de Ifranja ${ }^{17}$ e depois chegou a Zaragoza, onde capturou coisas incalculáveis e inestimáveis.

Em seguida, pôs-se em marcha, chegando a um castelo com cujos moradores topou e se combateram violentamente até que, depois de ataques e contra-ataques, ${ }^{18}$ Mūsà ordenou que suas tendas fossem levantadas, deixando à mostra suas filhas e mulheres, que ficaram expostas, e Mūsà apareceu no meio das tropas, de modo que todos os vissem, e então ergueu as mãos para Deus bendito e exalçado, passando a rogar, a pregar o anelo por Deus altíssimo e poderoso e a chorar; demorou-se nisso, e as pessoas começaram a quebrar, diante dele, as bainhas das espadas; destarte, Deus lhe concedeu a conquista e a vitória. Nunca nenhum exército comandado por Mūsà foi derrotado, até a sua morte, que Deus tenha dele piedade.

(409) Disse 'Abdulḥamīd:

Em seguida, Mūsà Bin Nușayr se embrenhou tanto nas terras do inimigo que as pessoas se aborreceram, considerando aquilo penoso, e disseram: "Aonde pretendes levar-nos? Basta-nos o que já temos em máos! Em que ponto pretendes nos fazer sair do mundo e alcançar mais ainda do que Deus já nos concedeu?". Então Mūsà riu, retirou-se e disse: "Por Deus que, caso me obedecêsseis, eu marcharia convosco até Constantinopla ${ }^{19}$ e a conquistaria, se Deus quisesse".

(410) Disse Ibn Rabīía:

Naquela época, todas as pessoas saquearam, com exceção de apenas quatro homens, que faziam parte dos seguidores dos companheiros do profeta: Abū 'Abdurraḥmān Alḥaballī, Ibn Šammāsa, Hanš Așṣan'ānī e 'Ayyāọ Bin 'Uqba Alfihrī.

(411) Disse [Ibn Rabī'a]:

Fui informado sobre um homem que então saqueou ouro e pedras preciosas, colocou-os numa resina e os derreteu $;^{20}$ depois, enquanto era atingido pela morte, pôs-se a gritar agonizante: “A resina! A resina!”.

\footnotetext{
16 "Até topar com um povo desnudo como bestas" traduz hattà atà qawman ma iṭan ka-lbahä’ im. O adjetivo ma itan, "desnudo", serve para esclarecer essa passagem, que sem ele fica obscura, como é o caso da crônica contemporânea do pseudo Ibn Qutayba.

17 "França", provavelmente.

18 "Depois de ataques e contra-ataques" traduz hattà jäla annās jawlatan, "até que as pessoas circularam". Trata-se de formulação difícil de traduzir.

${ }^{19} \mathrm{Na}$ crônica do pseudo Ibn Qutayba consta Rümyā, equivalente de "Roma".

${ }^{20}$ Formulaçáo obscura. Na crônica do pseudo Ibn Qutayba, "colocou numa caixa besuntada de resina”, sem referência ao derretimento. $\mathrm{O}$ termo usado é zift, que pode também significar piche, alcatrão etc.
} 
(412) Contaram-me, a partir de 'Abdulḥamīd, que o pai dele disse:

Foi para Alandalus uma perfumista que dali saiu com quinhentas cabeças; quanto ao que ela levou de ouro, prata, pedras preciosas e talheres, isso é incontável e ignorado.

(413) Disse ['Abdulḥamīd]:

Veio até nós da cidade de Medina um ancião de natureza e língua vigorosas, e nos falou a respeito de Alandalus. Perguntei-lhe: "Como sabes disso?", e ele respondeu: "É porque eu — por Deus! — sou um dos que foram lá aprisionados, e aquele que me comprou náo gastou com isso senão alguns grãos de pimenta que cabiam com folga num punho”.

(414) Disse ['Abdulhamīd]:

Um servo do califa Alwalid me informou e disse o seguinte:

Eu estava próximo do califa, que tinha diante de si uma bacia com cuja água se abluía quando lhe veio um emissário da parte do governador de Hurāsān para informar a respeito da conquista de uma das cidades daquela região; eu o avisei e ele disse: "Traze a carta dele", e mal concluíra a leitura quando lhe veio um emissário da parte de Mūsà Bin Nuṣayr para informar a respeito da conquista da região extrema de Sūs por seu filho Marwān; então o califa pôs-se a ler a carta, e mal a concluíra quando lhe veio outro emissário da parte de Mūsà para informar sobre a conquista de Alandalus. Então o califa agradeceu a Deus, louvou-o, voltou-se para mim e disse: "Segura a porta para mim e não deixa ninguém entrar", e assim procedi. Estava na casa um filho pequeno engatinhando diante dele. Alwalìd prosternou-se para Deus, em louvor, e enquanto isso o menino engatinhou até a bacia, caindo dentro dela; começou a se agitar e gritar, mas o califa não se voltou para ele e eu fiquei sem poder socorrer a criança pelo fato de o pai ter-me ordenado segurar a porta. Ele prolongou tanto a prosternação que temi pela morte da criança, mas então ele levantou a cabeça e gritou por mim; entrei e peguei-o, enquanto o califa prosseguia em seu mister. ${ }^{21}$

(415) Depois, por conta própria, Mūsà saiu fazendo algaras após a conquista das cidades de Tânger, de Alhaḍāà e de outras. Avançou até chegar a uma terra que se agitava sob os pés dos seus moradores, ${ }^{22}$ próxima ao mar inóspito, ${ }^{23}$ que ele contornou até chegar a uma ponte sobre a qual havia um ídolo de cobre ${ }^{24}$ com arco e flechas na mão; quando as pessoas se aproximaram, ele disparou uma flecha e matou uma pessoa, disparando a seguir outra que matou mais uma pessoa, e caindo em seguida; as pessoas se aproximaram e eis que era um ídolo de cobre.

\footnotetext{
21 "Enquanto o califa prosseguia em seu mister" traduz, sem certeza, a formulação wa 'innahu lamā bihi.

${ }^{22}$ Metáfora habitual em narrativas árabes para referir terras povoadas e prósperas.

23 "Mar inóspito" traduz albaḥr alaṣamm, literalmente "o mar surdo", denominação talvez derivada de baḥr azzulumāt (ou azzalām), "mar das trevas", como era conhecido o Atlântico.

24 "Cobre" traduz aqui nuḥ̄s, palavra que modernamente é utilizada com esse significado, mas que, no período medieval, poderia indicar qualquer outro metal, tanto que muitos tradutores preferem utilizar simplesmente "metal" para traduzi-la; há quem lance mão de "bronze".
} 
(416) Em seguida se disse a Mūsà: "Nestas areias existe uma torre que contém coisas espantosas", e ele avançou até lá, tentando, sem sucesso, invadi-la; ordenou então que fosse feita uma construção para subir na torre, até que lhe puderam ver o interior, e, quando aqueles que estavam construindo olharam lá dentro, riram e se atiraram lá de cima, caindo mortos. Mūsà gritou: “Quem subir ganhará cem dinares!". Um homem subiu e, assim que olhou lá dentro, riu e se atirou lá de cima. Ao ver aquilo, Mūsà disse: "Isto faz parte das coisas espantosas dos demônios", e bateu em retirada. ${ }^{25}$

(417) Disse Ja far Bin Alaštar:

Ouvi o meu pai contar o seguinte:

Eu estava com Mūsà Bin Nuṣayr, e cercamos um enorme castelo por cerca de vinte dias, mas não conseguimos invadi-lo. Quando aquilo nos pareceu muito longo, Mūsà gritou conosco: "Permanecei mobilizados!"; levantou-se no meio de nós, agradeceu a Deus, louvou-o e disse: "Irei à frente das fileiras, e quando vós me virdes dizendo 'Allāhu Akbar!', ${ }^{26}$ imitai-me e atacai". As pessoas disseram: "Louvado seja Deus! Mūsà perdeu a razão ordenando-nos fazer ataque contra pedras, pois não vemos senão paredes, e não há o que fazer!”. Em seguida, Mūsà avançou por entre as tropas e pôs-se a rogar, a provocar anelos e a chorar, enquanto nós nos mantínhamos parados esperando o seu 'Allāhu Akbar!', e então ele o fez, e todos o imitaram; em seguida atacou, e nós atacamos, e então ruiu a parte do castelo que estava diante de nós. Os soldados entraram e saíram com tantos cativos, butins e joias que era impossível contar.

(418) Abū Bakr nos contou, a partir de 'Abdulwahhāb, o seguinte:

Mūsà Bin Nuṣayr avançou e de repente se viu diante de um ídolo, à beira de um rio, ${ }^{27}$ de dedo em riste para frente; então ele avançou até um segundo ídolo que estava atrás desse primeiro ídolo, e cujo dedo apontava para o céu; então, ele avançou até um terceiro ídolo, que apontava com o dedo para os próprios pés; ao chegar a este terceiro ídolo, Mūsà disse: "Escavai", e então escavaram, e eis que havia ali um vaso selado. Mūsà ordenou que fosse aberto, e assim que o abriram saiu dele uma forte rajada de ar. Mūsà perguntou: "Acaso sabeis o que é isso?". Responderam: "Não". Ele disse: "Esse é um dos demônios aprisionados pelo profeta Salomão, a paz esteja com ele”. Em seguida, ele avançou até chegar a certa ilha do mar, na qual encontrou dezesseis jarras verdes seladas com o selo de Salomão, a paz esteja com ele. Ordenou que uma delas fosse quebrada, e então a quebraram, dela saindo

\footnotetext{
${ }^{25}$ Esse parece ser o núcleo de uma legenda que depois foi bastante reelaborada, tendo aparecido, já bem ampliada, no relato do letrado e viajante granadino Abū Ḥāmid Alg̉arnāṭi (m. 1169 d.C.), Tuhfat Alalbāb wa Nuhbat Ala' jāb (Joia das inteligências e seleção de espantos, Beirute/Abu Dabi: Șādir, 2003, p. 44-48), composto no Oriente como coleção de curiosidades sobre Alandalus. Mais ampliado ainda, esse relato foi tardiamente incluído, no século XVIII, no Livro das mil e uma noites, onde hoje se sedimentou entre as noites 567-577, sob o título de "Cidade de Cobre" (ou "de metal", ou, ainda, "de bronze").

26 "Deus é o maior”, formulação primordial no islã. O original lança mão de um verbo que designa a ação de dizer isso.

${ }^{27}$ No original, nahr min $m \bar{a}$, "rio de água".
} 
um demônio que chacoalhava a cabeça e dizia: "Juro por aquele que te dignificou com a verdade e a profecia, ó profeta de Deus, que depois disso nunca mais corromperei a terra e nem prejudicarei nenhuma criatura”. Então Mūsà ordenou que todas as outras jarras fossem devolvidas a seus lugares.

(419) Disse Ibn Habib:

Um homem venerável do Egito nos contou que Mūsà Bin Nuṣayr chegou até um rio em cuja primeira vertente encontrou ídolos machos do lado direito, e ídolos fêmeas do lado esquerdo. Depois ele avançou até chegar a uma terra que se agitava sob os pés dos moradores, e então as pessoas tiveram medo e fugiram dele. Depois ele avançou até chegar a certo ponto no qual se viu em meio a abóbadas de cobre; ordenou entáo que uma delas fosse quebrada, dela saindo um demônio que chacoalhava a cabeça e dizia: "A paz esteja contigo, ó profeta de Deus! Já me fizeste sofrer neste mundo!". Ao saber que não se tratava de Salomão, o demônio saiu em disparada, e Mūsà compreendeu que era um dos demônios aprisionados por Salomão, a paz esteja com ele, e ordenou que as outras abóbadas fossem deixadas para trás.

(420) Depois Mūsà avançou até que as pessoas foram envolvidas por uma forte treva que a todos espantou; em seguida, chegou a uma cidade que tinha um castelo de cobre; estacionou ali, caminhou por seu entorno, mas, não conseguindo adentrá-lo, gritou: "Quem escalará este castelo para ganhar cem dinares?”. Então um homem o escalou, e quando parou em pé na muralha caiu lá dentro. Mūsà então gritou pela segunda vez: "Quem escalará este castelo para ganhar mil dinares?”. Entáo outro escalou e fez o mesmo que o primeiro. Então Mūsà gritou pela terceira vez: "Quem escalará este castelo para ganhar mil e quinhentos dinares?”. Então um terceiro escalou e foi atingindo pelo mesmo que atingiu os outros dois. Mūsà disse: "Isso é uma enormidade!"; depois refletiu e disse: "Calma lá! Ainda irá chegar-vos uma notícia da qual gostareis, se Deus quiser”. Ato contínuo, ordenou que se trouxessem catapultas, que foram colocadas naquele castelo, e então ele disse: "Disparai!". Quando a pedra caiu no castelo, gritaram lá dentro, agitaram-se e disseram: “Ó rei, não somos nós o teu objetivo, nem quem desejas; somos um povo de gênios; portanto, deixa-nos!”. Mūsà lhes perguntou: “O que sucedeu aos meus companheiros?”. Responderam: "Estão conosco, intactos”. Disse-lhes: "Libertai-os para nós!”. Responderam: "Sim”, e os soltaram. Mūsà lhes indagou como estavam e o que lhes ocorrera, e eles responderam: "Nem percebemos onde estávamos, e não fomos atingidos nem sequer por um espinho!". Mūsà disse: "Graças a Deus, o senhor dos mundos".

(421) Depois, ele marchou com suas tropas conquistando tudo por onde passava, até chegar ao Oceano Circundante, ${ }^{28}$ o qual nunca foi navegado por ninguém, e em cujas águas ninguém se aprofundara. Ordenou que fossem levadas três águias, e quando se aprofundassem bastante que soltassem uma águia; depois, aprofundando-se mais, soltassem outra

\footnotetext{
28 "Oceano Circundante" traduz Albaḥr Almuhịt, que conforme a antiga concepção geográfica árabe era o mar que circundava a terra toda. Hoje se usa também para o Oceano Atlântico.
} 
águia, e quando se aprofundassem mais ainda, soltassem a terceira águia. Então soltaram a primeira águia, que avançou como Deus quis e não voltou; depois, soltaram a segunda, que saiu em linha reta e não voltou; depois, soltaram a terceira, que se aprofundou e depois retornou, caindo dentro do barco; souberam então que não havia ninguém atrás deles nem à sua frente.

(422) Disse 'Abdulmalik:

A entrada de Mūsà em Alandalus se deu um ano após Ṭāriq, e nela permaneceu por dois anos e um mês; depois, retornou à Ifrīqya montado num asno chamado Alkawkab. ${ }^{29}$ Quando chegou a Almāi ida, voltou o rosto para a cidade de Córdoba e disse: "Ai de ti, como és deliciosa e nobre, e quão espantosos são os teus desígnios! E que Deus te amaldiçoe daqui a duzentos anos". ${ }^{30}$ Depois avançou até chegar a Alhaḍrā', e ordenou que carros transportassem as gemas, o ouro, a prata e várias espécies de indumentárias de Alandalus.

A entrada de Mūsà Bin Nușayr em Alandalus foi no mês de jumādà primeira, no ano de noventa e três da Hégira, quando ele tinha sessenta anos. Mūsà permaneceu em Ifrīqya dezesseis anos como governador, e de lá se retirou no ano de noventa e cinco.

(423) Quando Mūsà entrou em Ifrīqya, encontrou-a numa terrível seca, e então ordenou às pessoas que jejuassem e saíssem dali, os homens num grupo, as mulheres noutro grupo, os meninos noutro grupo, as vacas noutro grupo, os bezerros noutro grupo, as ovelhas noutro grupo, os carneiros noutro grupo, e os não muçulmanos ${ }^{31}$ noutro grupo. Todos se reuniram num só local. Mūsà rogou a Deus altíssimo e poderoso, e as pessoas rogaram com ele, e choraram os homens, choraram as mulheres, choraram os meninos, e gritaram as vacas, e os bezerros, e as ovelhas, e os carneiros, e os não muçulmanos, até que foi como se os céus se fechassem sobre a terra; assim permaneceu até o meio-dia; ele fez um sermão e, como não citasse o califa, perguntaram-lhe: "Não vais rogar pelo califa?", e ele respondeu: "Nesta situação não se roga ao califa, mas apenas a Deus altíssimo e poderoso”. E então receberam uma chuva que lhes trouxe água.

(424) Depois Mūsà saiu de Ifrīqya, deixando como sucessor o seu filho 'Abdullāh, e levou consigo cem homens dentre os notáveis berberes, vinte dos reis bizantinos, cem dos reis de Alandalus, e todos saíram com ele carregando as diversas espécies de coisas que havia em cada país, suas preciosidades, seu ouro, sua prata, suas gemas, suas esmeraldas, seus escravos, enfim, coisas incontáveis, sobre as quais ninguém jamais ouvira, até que chegou ao Egito, onde não houve nobre nem notável nem alfaqui nem poderoso que não fosse falar-lhe. Mūsà pagou dez mil dinares ao filho de Sulaymān Bin 'Abdulmalik, e depois saiu do Egito em direção à Palestina, onde foi recebido pela família de Rūḥ Bin Zanbāé, com a qual se

\footnotetext{
29 "O astro".

${ }^{30}$ Em sua edição, Jorge Aguadé observa que em uma obra histórica bem posterior, Albayān Almug்rib, de Ibn 'Iḍārī (m. 1295 d.C.), fala-se em trezentos anos, e não em duzentos.

31 "Não muçulmanos" traduz ahl aḍdimma, "protegidos", categoria normalmente constituída por cristãos, judeus e, ao menos nos primórdios do islā, zoroastristas.
} 
hospedou, e eu fui informado de que lhe sacrificaram cinquenta camelos. Depois saiu de lá, deixando com eles alguns de seus companheiros e de seus filhos menores, e distribuiu para aquela família um mundaréu de escravos e escravas etc.

(425) Entáo o califa Alwalīd, tendo adoecido da doença que o mataria, escreveu a Mūsà ordenando-lhe com veemência que fosse até ele a fim de vê-lo antes de morrer, enquanto Sulaymān, ${ }^{32}$ irmão de Alwalīd, lhe escrevia para que fosse vagaroso em sua marcha, pois Alwalīd exalava seus últimos suspiros. Mūsà agiu conforme a carta de Alwalīd, e deixou de agir conforme a carta de Sulaymān, marchando com rapidez. Sulaymān jurou entáo que, quando tivesse Mūsà em seu poder, o crucificaria sem dúvida. Alwalīd ordenara a Mūsà que se apressasse, a fim de impedir que Sulaymān apoderasse das coisas que trazia, enquanto Sulaymān lhe pedia que fosse vagaroso para impedir que os filhos de Alwalīd apoderassem das coisas que trazia.

(426) Disse 'Abdulmalik: É assim que os homens se arrastam para si mesmos, e o próprio mundo os arrasta para si, tomando-lhes o que lhes deu sem que eles possam tomar-lhe o que lhe deram.

(427) Mūsà chegou antes da morte de Alwalīd, e lhe deu as preciosas pérolas, rubis, esmeraldas, belas escravas e escravos e a mesa de Salomão, sejam as preces de Deus sobre o nosso profeta e sobre ele, bem como as coroas cravejadas de pérolas e rubis. Alwalīd se apossou de tudo e ordenou que a mesa de Salomáo fosse quebrada, apossando-se das joias mais valiosas que continha; já todo o ônix que havia nas coroas, ele o depositou no tesouro público.

(428) Depois não tardou que Alwalīd morresse, e o califado passou para o seu irmão Sulaymān, que mandou chamar Mūsà, tratou-o com injúrias e disse: "Por Deus que vou acabar contigo, dispersar os teus e te rebaixar". Mūsà respondeu: "Quanto a acabares comigo e me rebaixares, isso está nas mãos de Deus e é para Deus, não para ti, e é nele que busco apoio contra ti”. Então Sulaymān ordenou que ele fosse deixado em pé, num dia de verão de intenso calor. Mūsà era um homem enorme, corpulento, de carnes fartas, e ficou em pé até cair desmaiado, isso na presença de 'Umar Bin 'Abdul'azīz, ${ }^{33}$ que depois diria: "Não tive em minha vida um dia mais triste do que esse, devido à retidão daquele homem e aos distantes lugares a que foi pela causa de Deus, e às conquistas que Deus nos concedeu por meio de suas mãos". Ao ver Mūsà cair desmaiado, Sulaymān disse a 'Umar: "Ó Abū Ḥafṣ, creio que não andei direito!”. 'Umar respondeu: "Decerto, comandante dos crentes!”. Sulaymān perguntou: "Quem o recolherá?", e então Yazīd Bin Almuhallab se levantou e disse: "Eu, comandante dos crentes, o levarei comigo". Sulaymān disse: "Leva-o, pois, e não o maltrates". Então Yazĩd saiu com Mūsà e lhe ofereceu uma montaria, na qual ele subiu, permanecendo

\footnotetext{
${ }^{32}$ Alwalīd Ibn 'Abdulmalik, sexto califa da dinastia omíada, governou em Damasco de 705 a 715, tendo sido sucedido por seu irmão Sulaymān Ibn 'Abdulmalik, que governaria até 717 .

33 'Umar Ibn 'Abdul 'azīz foi o oitavo califa omíada, tendo governado de 717 a 720 . É considerado exemplo de piedade mesmo pelos historiadores hostis à sua dinastia.
} 
na casa de Yazīd por alguns dias, e então as coisas entre Mūsà e Sulaymān melhoraram, e ele pagou um resgate de um milhão de dinares.

(429) Certa noite, Yazīd conversava com Mūsà na casa deste e lhe perguntou: "Ó Abū 'Abdurraḥmān, quanto calculas serem teus serviçais e a gente da tua casa?". Mūsà respondeu: "Muitos". Yazīd perguntou: "Seriam mil?", e Mūsà respondeu: "Mil, e mais mil... até perder a respiração”. Disse Yazīd: “E, apesar de estares na situação que descreveste, te lanças por tuas próprias mãos na aniquilação? Por que não te mantiveste na tranquilidade proporcionada por tua força e na tua posição de poder, resguardando-te por meio daquilo que trouxeste? Ou te aceitariam ou então empregarias a tua força e a tua posição de poder!”. Mūsà respondeu: "Por Deus que, se assim eu tivesse desejado, não me tomariam nada até o Juízo Final, mas eu decidi dar a preferência a Deus altíssimo e poderoso, e desconsiderei a possibilidade de ir contra a obediência e a comunidade". ${ }^{34}$

(430) Disse ['Abdulmalik]:

Fui informado de que Sulaymān perguntou a Mūsà: "Em que te refugiavas quando atacavas e encontravas o inimigo?". Respondeu: "Nos rogos e na paciência quando do encontro". Perguntou: “Qual tipo de cavalo era o mais veloz naqueles países?”. Respondeu: “Os baios”. Perguntou: "Qual dos povos lutava mais tenazmente?”. Respondeu: "São mais do que eu possa contar". Perguntou: "Fala-me a respeito dos rūmīs". ${ }^{35}$ Respondeu: "Leóes em suas fortalezas, águias em seus cavalos, mulheres em suas escoltas; se encontram alguma oportunidade, aproveitam-na; se topam com campeóes, são cabritos correndo para as montanhas, e não consideram a derrota uma vergonha". Perguntou: "Fala-me sobre os berberes". Respondeu: "São o povo mais parecido com os árabes em confronto, socorro, paciência, heroísmo e tolerância; contudo, são os mais traiçoeiros, sem lealdade nem fidelidade". Perguntou: "Fala-me sobre a gente de Alandalus". Respondeu: "Reis amolecidos pela opulência e cavaleiros que não se acovardam". Perguntou: "Fala-me sobre os ifranjes". ${ }^{36}$ Respondeu: "Entre eles existe a grande quantidade e o equipamento, firmeza, força, coragem e socorro". Perguntou: "Informa-me como foi a guerra entre vós e eles: acaso foi a teu favor, ou contra ti?”. Respondeu: “Quanto a isso, por Deus que nunca nenhum estandarte meu foi derrotado, nem nenhuma legião minha dispersada, nem comigo os muçulmanos foram vencidos desde que adentrei os quarenta anos até que cheguei aos oitenta”. Então Sulaymān riu e se admirou de suas palavras.

(431) Sulaymān ordenou que trouxessem uma bacia enorme e se pôs a contemplá-la. Mūsà lhe disse: "Estás admirado sem motivo. Por Deus que não considero que ela valha dez mil dinares; por Deus que enviei ao teu irmão Alwalīd um touro de topázio verde no qual ele despejava leite, e o leite ficava verde, e nele podias ver um fio de cabelo branco; foi avaliado em cem mil dinares, e é do que de mais barato enviei a ele. Consegui isto, consegui aquilo...”,

\footnotetext{
34 "Ir contra a obediência e a comunidade" traduz alhurūj 'ani-țtàa a wa-ljamā' $a$, conceito de submissão caro ao islã sunita, por pressupor a prevalência do interesse comum.

${ }^{35}$ Palavra que normalmente indica "bizantinos", mas não parece ser o caso aqui.

${ }^{36}$ É possível que se trate de referência aos franceses.
} 
e se pôs a fazer a relação das gemas, pérolas, rubis e esmeraldas que conseguira, a ponto de deixar Sulaymān estupefato.

(432) Abdulḥamīd nos relatou, da parte de seu pai, o seguinte:

Sulaymān foi passear em uma de suas propriedades, e Mūsà Bin Nuṣayr foi com ele. Passaram por um lugar com gado, ${ }^{37}$ o qual se avaliou conter mil reses ou algo próximo. Admirado com tamanha quantidade, Sulaymān voltou-se para Mūsà e perguntou: "Tens essa quantidade de gado?". Mūsà riu e respondeu: "Por Deus que o meu servo mais humilde tem o dobro disso". Sulaymān perguntou: "O teu servo mais humilde?!". Mūsà respondeu: "Sim, por Deus!", e repetiu a frase várias vezes, dizendo em seguida: "Isso não é nada perto do que Deus me concedeu, ou concedeu por meu intermédio. As mil reses então se vendiam por dez dirhams, ${ }^{38}$ cada cem por um dirham. As pessoas passavam com vacas e ovelhas e ninguém olhava para elas. Eu vi grupos de três a dez camelas por um dirham, e também um homenzarrão ${ }^{39}$ vivaz com mulher e filhos por cinquenta dirhams".

(433) Sulaymān foi peregrinar a Meca e junto com ele foi Mūsà, que era a pessoa mais entendida no saber a respeito dos astros. ${ }^{40}$ Quando chegaram à cidade de Medina, Mūsà disse a certa pessoa que lhe era muito cara: "Efetivamente morrerá depois de amanhã um homem cuja fama chegou ao Oriente e ao Ocidente”. E então Mūsà morreu no segundo dia, e Maslama ${ }^{41}$ liderou as preces em intenção de sua alma.

Menção dos governadores de Alandalus, desde o dia em que foi conquistada até o ano duzentos e setenta e cinco da Hégira, com o relato de certas ocorrências e coisas que foram vistas em certos países, desde os tempos antigos

(434) 'Abdulmalik nos contou, a partir de Ibrāhīm Bin Almundir Alḥuzāmī, a partir de Alwāqidī, o seguinte:

\footnotetext{
37 "Lugar com gado", aqui, traduz um sintagma incompreensível: uma primeira palavra constituída pelas letras $m n y t$, seguida de $b i-\underline{d} a w d$ min $\dot{g} a n a m$. É possível no trecho que haja algum erro de cópia não corrigido ou detectado pelo responsável pela edição.

${ }^{38}$ Moeda que normalmente tinha um valor bem mais baixo do que o dinar.

39 "Homenzarrão" traduz 'ilj, que pode indicar também "asno", mas não parece ser o caso. Segundo Miguel Nimer, 'ilj significa em árabe "onagro, burro; burro selvagem, gordo e forte; todo o infiel gordo e alto, estrangeiro à raça e à língua árabe. (...) Todo o homem barbado; o imberbe não se diz “ilj”. Essa palavra, também conforme citação de Nimer, é origem do termo português "elche", "cristấo ou mouro renegado, na Índia portuguesa” (Influências orientais na língua portuguesa. São Paulo: Edusp, 2005, p. 60).

40 "Saber a respeito dos astros" traduz 'ilm annujūm, que poderia ser traduzido como astronomia ou astrologia, mas considerou-se mais adequado empregar uma locução neutra, para evitar as associaçóes automáticas, hoje, com ciência e superstição.

${ }^{41}$ Possível referência ao líder político e militar Maslama Bin 'Abdulmalik, irmão do então califa Sulaymān, homem de grande notoriedade na época devido às suas façanhas militares. Destarte, ao informar que as preces pela alma de Mūsà foram comandadas por Maslama, informa-se simultaneamente da grande importância que se lhe atribuía.
} 
Ṭāriq permaneceu um ano em Alandalus, desde o dia em que a conquistou até o dia em que a deixou. Depois dele, Mūsà ficou ali por dois anos e alguns meses; depois dele, 'Abdul 'azīz Bin Mūsà, por dois anos; depois Alḥurr Bin 'Abdurraḥmān Atțaqafī, por dois anos e oito meses; depois, Assamiḥ Bin Mālik Alhūūānī, por dois anos e nove meses; depois, 'Anbasa Bin Sahīm Alkalbī, por quatro anos e cinco meses; depois, Yaḥyà Bin Salāma, por dois anos e seis meses; depois, governou-a Ḥudayfa Alaḥwaș Al'ibsī por um ano; depois, 'Uțmān Bin Abī Nis'a Alhuțtamī, por cinco meses; depois, Alhaytam Bin 'Ubayd por quatro meses; depois, governou-a 'Abdurraḥmān Bin 'Ubaydullāh por dois anos e oito meses; depois, governou-a 'Abdulmalik Bin Qațan Alfihrī por quatro anos; depois, 'Uqba Bin Alḥajjāj Assalūlī, por cinco anos e dois meses; depois, Balj Bin Bišr Alqīsī, por onze meses; depois dele, e dizem que com ele, governou-a Tá laba Bin Salāma Al'āmilĩ em cinco [desses onze] meses; depois, rebelou-se contra ele 'Abdurraḥmān Bin Ḥabīb e Umayya e Qạ̣an e Yūsuf, juntamente com os seus seguidores: combateram-no e ele morreu sete dias após a batalha; depois, governou-a Abū Alḩațāār por dois anos; depois, governou-a Abū Tawwāba Aljuḍāmī por um ano; depois, Yūsuf Bin 'Abdurraḥmān, por sete e nove meses.

(435) Depois, governou-a 'Abdurraḥmān Bin Mu'āwya Bin Hišām Bin 'Abdulmalik Bin Marwān, que Deus esteja satisfeito com eles todos, e foi assim: ele entrou em Alandalus e Yūsuf deslocou-se até ele e o enfrentou na Mușāra de Córdoba, ${ }^{42}$ sendo derrotado por 'Abdurraḥmān Bin Mu'āwya, que se apoderou do reinado e entrou no palácio naquele mesmo dia, tendo seu poder reconhecido no dia da Festa do Sacrifício, uma sexta-feira do ano de cento e trinta e oito. Ele ficou no governo de Alandalus por trinta e três anos e quatro meses.

(436) 'Abdullāh Bin Aššamar me informou que seu pai, Šamar, dava aulas para os filhos de 'Abdurraḥmān Bin Muwaya, e que ele próprio assistia às aulas com eles, e que foi circuncidado junto com eles; também me informou que em menino costumava ir ao Portão de Assadda, do Palácio do Córdoba, por ali entrando, até chegar ao comandante 'Abdurraḥmān em seu lugar de assembleia, sem que ninguém o impedisse.

(437) Depois se empossou o seu filho Hišām Bin 'Abdurraḥmān Bin Mu'āwya, que permaneceu no governo dois anos e dez meses. Era de conduta louvável e distribuía muita esmola.

(438) Depois se empossou o seu filho Alḥakam Bin Hišām Bin 'Abdurraḥmān por vinte e sete anos e um mês e meio. Morreu numa quinta-feira, três dias antes do fim do mês de $\underline{d} \bar{u}$ alhijja do ano de duzentos e seis.

(439) Depois se empossou o seu filho 'Abdurraḥmān Bin Alḥakam Bin Hišām numa noite de sexta-feira, e no governo ele permaneceu por trinta e um anos, três meses e quatro

\footnotetext{
42 "Na Mușāra de Córdoba" traduz bi-lmușāra min Qurțba. Esse lugar é citado várias vezes em obras históricas sobre Alandalus, sem mais informaçóes sobre sua localização exata. No enorme compêndio Nafḥ Atṭīb min Guṣn Alandalus Arrațīb (O aroma trescalante do fresco ramo de Alandalus), do historiador tlemceniano Šihāb Addīn Aḥmad Almaqqarī (1578-1632), informa-se incidentalmente, em pormenorizada descrição desse mesmo episódio, que se trata de uma região desértica a oeste de Córdoba, entre essa cidade e Sevilha (ed. de I. 'Abbās, Beirute, s/d: Șādir, v. III, p. 33).
} 
dias. Morreu na noite de uma quinta-feira, e era — Deus dele se apiede — um comandante generoso, poeta e letrado. ${ }^{43}$

(440) Depois se empossou o seu filho Muḥammad Bin 'Abdurraḥmān Bin Alḥakam numa noite de quinta-feira, dia três do mês de rabī' alähir, do ano de duzentos e trinta e oito, e permaneceu no governo trinta e cinco anos menos um mês e quatro dias. Morreu numa noite de quinta-feira no início do mês de rabī alawwal do ano de duzentos e setenta e três.

(441) Depois se empossou o seu filho Almundir Bin Muḥammad Bin 'Abdurraḥmān num domingo à tarde, quatro dias após a morte do seu pai, e isso porque ele estava ausente de Córdoba, numa das batalhas empreendidas por seu pai. Permaneceu no governo vinte e três meses.

(442) Depois se empossou o seu irmão 'Abdullāh Bin Muḥammad Bin 'Abdurraḥmān. Foi um governo decaído, que fez decaírem todos os pactos e tréguas firmados por seu pai e seu avô; em seu governo sucederam-se as afliçôes, no seu decurso sendo capturados crianças e bens, falindo os mercados e aumentando os preços; nela, o vil se fortalecia, e o nobre se humilhava; Córdoba, a amaldiçoada, a corpulenta, a gorda, a derrotada, a humilhada, ocupada no final dos tempos por berberes que corrompiam a cidade e o deserto.

(443) Costuma-se dizer:

Córdoba, a adúltera. Será sua ruína a segunda carnificina! Cheia de abominaçôes, amiga de cafetôes, ${ }^{44}$ de cárceres e flagelos, desleal com pactos e anelos, sucede-lhe infâmia atroz quando atacada por cavalaria veloz, em galope chocante, vinda de muito lugar distante, pelas mãos de alguém de trompa ${ }^{45}$ um calouro de mau agouro, os muçulmanos na sua vanguarda, e os infiéis na retaguarda. Que todos fujam para Carmona: oh, que abraço de marafona!

(444) E também se dizia:

Sevilha dos filhotes de leão, aduladora de crianças e meninos, ${ }^{46}$ que socorre o estrangeiro e leva os seus naturais à indigência: será butim, no final dos tempos, de homens que virão de longe, cavaleiros que se atirarão sobre ela como abutres.

\footnotetext{
${ }^{43}$ Conforme observa J. Aguadé, a partir do próximo parágrafo o texto não pode ser de Ibn Ḥabīb, pois são referidos fatos posteriores à sua morte; seriam inclusão de um dos copistas, Yūsuf Bin Yaḥyà Almaġāmī, morto em 901 d.C./300 H.

44 "Amiga dos cafetóes" é tradução de țāliqat alaṭlāq. J. Aguadé usa "desenfreada".

45 "Pelas mãos de alguém de trompa" traduz, quase literalmente, o obscuro sintagma 'alà yaday dîll-ḩurțūm, "pelas mãos do portador da tromba" (pode também indicar o condutor do elefante). $\mathrm{O}$ tom enigmático, reforçado pelas rimas (asjāa ) e aliteraçóes, é aqui programático, dado o caráter de praga/vaticínio do discurso, o que o aproxima também de antigos discursos de sacerdotes, em especial no período pré-islâmico.

${ }^{46}$ Entenda-se: pela concepção antiga, meninos devem ser tratados com rigor, e não adulados, pois isso os corrompe, efemina e arruína as futuras geraçóes. Por isso, ambas as formulaçóes, Išbīlyat alašbāl, "Sevilha dos leôezinhos", e dājinat alațäl wa-l 'iyāl, "aduladora de crianças e meninos", funcionam em uma relação de complementaridade: os meninos são leóezinhos, isto é, selvagens perigosos, justamente porque adulados. E, claro, saboreia-se a aliteração, trocadilhesca e não cognata, entre Išbillya, "Sevilha", e ašbāl, "filhotes de leáo". A semelhança fonética não era pensada como meramente casual: lembre-se do sonho de Almanșūr (m. 1002 d.C.), famoso governante árabe de Alandalus, comendo aspargos, e isso o fez ter a certeza de que conquistaria o Reino de Leão, pois aspargo, em árabe, se diz hālyūn, que também pode ser entendido como "Eis aqui Leão".
} 
(445) E também se dizia:

Toledo das ruínas, construída entre tumultos e assassinatos; se fizerem a paz com os associacionistas não lhes restará vulgo nem reino; pelas mãos de seu povo surgirá a corrupção, e as pessoas dali fugirão.

(446) E também se dizia:

Écija, a prostituta, lembrada com maldição e infâmia; o que ela tem de bom partirá, e o que tem de ruim permanecerá.

(447) Disse Ka'b:

O início deste país foi com o profetismo e a piedade; depois, poder, soberba, arrogância e corrupçáo, os homens se mordendo uns aos outros como asnos, e todos nesse dia serão amigos da divulgação e inimigos do segredo; o homem jejuará, e de seu jejum não sentirá senão a fome, e rezará, e da reza não obterá senão a vigília e a fadiga, e peregrinará, mas sua peregrinação não se aceitará, e dará esmolas, mas suas esmolas não se aceitarão, e pagará o dízimo, e esse pagamento não se aceitará, e isso porque, devedor de cem ou de cinquenta dinares, dará dez dinares como esmola para que as pessoas vejam que ele dá esmolas e paga o dízimo.

(448) Disse 'Abdulmalik:

Ṭaliq Bin Assamaḥ Almuāafirī nos contou, a partir de Ḍammām Bin Ismāềl, o seguinte:

Ouvi Al'alā' Bin Katīir e 'Abdullāh Bin Sulaymān contando que o apóstolo de Deus, que Deus o bendiga e salve, disse:

São cinco as coisas que espero não vos alcancem - e livre-nos Deus de que as alcanceis ou de que vos alcancem. As abominaçóes, no meio de quaisquer gentes, não se difundem senão quando Deus lhes impóe peste e dores que não estavam em seus antepassados; sempre que trapaceiam nos pesos e medidas, Deus os faz experimentar o sofrimento, a dureza da morte e a iniquidade do potentado; sempre que se impedem de pagar o dízimo com seu dinheiro, Deus impede que a chuva lhes chegue — não fossem as montarias, não beberiam; sempre que traem o compromisso com Deus e o compromisso com seu profeta, Deus lança contra eles inimigos que lhes tomam parte do que possuem; sempre que os seus líderes julgam com falsidade, Deus faz com que esse mal incida sobre eles. ${ }^{47}$

(449) Contou-se igualmente que o apóstolo de Deus, Deus o bendiga e salve, disse: "O que fareis quando vossos jovens prevaricarem, vossas mulheres tiranizarem, vossos ignorantes multiplicarem-se, vossos dissolutos soltarem as rédeas, e vosso jihäd for impedido?". Perguntaram: "Mas isso acontecerá, apóstolo de Deus?". Respondeu: "Sim, e pior ainda! $\mathrm{O}$ que fareis quando o crente quedar-se solitário e isolado no bairro, espoliado, odiado e maltratado como se maltrata uma carniça de asno? $\mathrm{O}$ que fareis quando surgirem os instrumentos de corda e os vinhos, e quando os últimos desta naçáo amaldiçoarem os primeiros?”.

\footnotetext{
${ }^{47}$ Segundo o responsável pela edição libanesa, essa tradição está presente na coletânea do letrado e tradicionista Albayhaqī (994-1066 d.C.), considerada uma das legítimas pelas autoridades religiosas muçulmanas.
} 
Perguntaram: "E eles rezarão, apóstolo de Deus?". Respondeu: "Sim, mas quantos rezadores não têm nenhum caráter? $\mathrm{O}$ que fareis quando Deus vos extraviar e vos impuser quem não terá piedade nem misericórdia por vós?". Disseram: "E isso vai acontecer, apóstolo de Deus?". Respondeu: "Sim, e ainda pior".

(450) Dizia-se:

Córdoba, a adúltera, odiada por Deus; quando os povos de vários países nela se reúnem, e nela se multiplica a perversidade, o adultério e a corrupção, nesse momento então Deus faz desabar sobre ela a sua força. Quando vires as sediçôes prorrompendo em Alandalus, deverás juntar ouro, prata e cavalo ligeiro, e depois o mal se movimentará entre duas montanhas: a vermelha e a negra; o início disso tudo será no mês novo, que é ramaḍan, e o que lhe sucede, e ainda o seguinte, e depois ocorrerá uma grande matança em Córdoba, na confluência da Casa da Injustiça ${ }^{48}$ Ó gente de Córdoba, cuidado com vossas mulheres e filhos: não os façais morar nas proximidades da confluência da Casa da Injustiça, nem nas proximidades da Grande Mesquita, pois será uma matança na qual não haverá piedade para meninos nem para mulheres, num dia de quinta-feira, entre as preces do meio-dia e do entardecer, até o pôr do sol. Um dos lugares mais seguros será o morro a que chamam Morro de Abī 'Abda, ${ }^{49}$ junto à igreja.

(451) Disse Ibn Abī Arriqā:

Um homem dotado de saber me informou que o lugar onde fica essa igreja é nas vizinhanças da casa de Așbag Bin Ḩalīl.

(452) Ouvi 'Abdulmalik Bin Habīb dizer:

Se acaso o governo dos omíadas se retirar e tomar o poder um não árabe ${ }^{50}$ ou um berbere, em cujo governo se dará a anexação, e num outro governo dos omíadas acontecerá a carmonização, ${ }^{51} \mathrm{em}$ seguida Córdoba se arruinará a ponto de não ser habitada senão pelos corvos, e o poder se mudará para Sevilha, e o califado sairá das máos dos descendentes de Al'abbās, passando o poder para os descendentes de Abū Ṭālib, ${ }^{52}$ até que aparecerá o gran-

\footnotetext{
${ }^{48}$ Trata-se, obviamente, de uma metáfora.

${ }^{49}$ Observa J. Aguadé que não existem referências a tal morro nos registros históricos.

50 "Não árabe" traduz rajul min almawālì, plural de mawlà, categoria étnico-social de muçulmanos de origem não árabe, cuja importância variou ao longo do tempo.

51 "Carmonização" traduz qarmūniyya, "relativo a Carmona". Pode aludir — tenha-se em conta que tal gênero vaticinatório é programaticamente obscuro - a uma possível transferência da sede de poder para Carmona. Sabe-se que, de 1013 a 1067, existiu a chamada taifa (denominaçáo dada a cada um dos reinos independentes que se formaram com a fragmentação do poder central muçulmano em Alandalus no século XI) de Carmona, cuja base era nessa cidade, governada pela dinastia berbere dos zenatas. A cópia do manuscrito, não custa lembrar, é do final do século XIII d.C., embora Aguadé nem sequer avente a possibilidade de uma interpolaçáo referente a um período táo tardio. Seja como for, conforme observa agudamente o mesmo Aguadé, esse gênero de discurso escatológico não se referia a "fatos" em concreto.

${ }^{52} \mathrm{Al}$ 'abbās (m. 653 d.C.), tio paterno do profeta, ancestral dos abássidas, dinastia que tomou o califado dos omíadas no Oriente em meados do século VIII; Abū Țālib, também tio do profeta, pai de 'Alī, quarto califa, cuja derrubada pelo fundador da dinastia omíada, Mu'āwya Ibn Abī Sufyān, no século VI, foi a causa do surgimento do xiismo.
} 
de embusteiro, ${ }^{53}$ e virá alguém proveniente da tribo de Qurayš, descendente de Fátima, ${ }^{54} \mathrm{e}$ o povo de Alandalus lhe entregará o poder; no tempo desse fatímida Constantinopla será conquistada, e pelas mãos desse mesmo fatímida os cristãos serão mortos em Córdoba e seus distritos, e não restará um único cristão, e sua descendência sofrerá cativeiro, a tal ponto que uma criada se comprará em troca de alguns alfinetes, e um criado imberbe, em troca de um chicote.

(453) E Ibn Abī Šamar me informou ter ouvido Ḥassān falando sobre esse assunto.

(454) Disse 'Abdulmalik:

Eu fui informado de que Albarrā' Bin 'Āzib disse:

O apóstolo de Deus, Deus o bendiga e salve, disse: "Não existe nenhuma espécie de pecado cometida pelos povos que não será cometida pelo povo deste país no final dos tempos, com o acréscimo de duas coisas: profanação de túmulos e copulação com mortos".

(455) E ele também disse, Deus o bendiga e salve: "Deus me livre de um tempo no qual dominam os menores, os maiores ficam à espera, e no qual a morte de ambos se aproxima".

(456) E Anas Bin Mālik ${ }^{55}$ disse: "As coisas ficarão cada vez mais duras, os homens ficarão cada vez mais avarentos, e a hora final não chegará senão por causa da perversidade dos homens".

(457) E Anas Bin Mālik relata que o apóstolo de Deus, Deus o bendiga e salve, disse: "O mundo não acabará senão quando os jinns ${ }^{56}$ se associarem a vós em vossos filhos". Perguntaram-lhe: "Como distinguiremos nossos filhos dos deles, apóstolo de Deus?". Respondeu: "Pela falta de vergonha e impiedade, e o mais desavergonhado será aquele que se dá à sodomia".

(458) E Anas Bin Mālik também relata que o profeta disse: "Em meu povo haverá os büriyyün". Perguntaram-lhe: "E o que são os büriyyūn, apóstolo de Deus?”. Respondeu: "Homens perspicazes nas coisas de sua vida mundana, torpes com as coisas de sua outra vida, que morrerão desprezivelmente".

(459) Disse Anas Bin Mālik:

O apóstolo de Deus, Deus o bendiga e salve, disse a Ibn Mas'ūd: "O que seria de ti se acaso estivesses em meio a uma escória de gente cujo desrespeito por pactos e pela lealdade e cujas divergências entre si a levaram a tal condição?”. Respondeu: “Como eu deverei agir se

\footnotetext{
53 "Grande embusteiro" traduz addajjäl, palavra que, em outros contextos e precedida de Almasīh , "Messias", significa "Anticristo".

${ }^{54}$ Tribo mequense da qual provinha o profeta Maomé, e da qual, segundo a maioria dos muçulmanos, deveriam descender os califas. E Fátima é o nome da filha do profeta, que se casou com o seu primo 'Alī, e da qual se diziam descendentes os membros da dinastia xiita dos fatímidas, que governou uma parte do norte da África (especialmente a região da Tunísia) e depois estabeleceu no Egito um califado extinto, no século XII, por Șalāh Addīn (Saladino).

55 Teólogo e tradicionista muçulmano (612-712) nascido na Arábia, companheiro de Maomé e fundador de uma das quatro escolas de jurisprudência islâmica, a malikita, justamente a que predominou em Alandalus.

${ }^{56}$ Criaturas sobre-humanas, "gênios".
} 
eu me vir em tal situação, apóstolo de Deus?”. Respondeu: "Fica totalmente grudado em tua casa até que te advenha morte natural ou assassinato". ${ }^{57}$

(460) Disse 'Abdulmalik:

Fui informado de que o apóstolo de Deus disse: "Minha nação sofrerá neste mundo sete tipos de tortura. Um grupo será tragado pela terra; contra outro grupo serão enviadas pedras; contra outro grupo serão enviadas ventanias que o lançarão na água; um grupo será afogado pelas chuvas; outro grupo será aniquilado pela espada, ou seja, pelas sediçóes e matanças; contra outro grupo serão enviadas cobras e escorpióes com asas, que o devorarão; e outro grupo vai viver na pândega e na falsidade, e então será transformado em macacos e porcos”. Perguntaram: “E quando isso acontecerá, apóstolo de Deus?”. Responder: "Quando tomarem vinho, vestirem seda, ouvirem cantoras e os homens se bastarem aos homens, as mulheres às mulheres, e abandonarem o livro de Deus e as puniçóes nele previstas”.

(461) Fui informado de que Abū Hurayra ${ }^{58}$ disse:

A fome entre as pessoas será tamanha que se um homem chegar com seu escravo e disser: "Dai-me um punhado de tâmaras por este escravo", isso lhe será recusado.

(462) Fui informado de que o apóstolo de Deus, Deus o bendiga e salve, disse: "Estareis a ponto de que todos os povos se lancem contra vós". Perguntaram: "Por que, apóstolo de Deus? Por sermos poucos?". Respondeu: "Não, por Deus! Sois muitos, porém cheios de sujeira, tal como a sujeira arrastada por uma torrente, e isso extrai o temor do coração de vossos inimigos, lançando-o em vossos coraçóes". Perguntaram: "E por que isso, apóstolo de Deus?". Respondeu: "Por causa do amor pela vida e pelo desgosto com a morte".59

(463) E ele também disse, Deus o bendiga e salve: "Chegar-se-á ao ponto de a aflição atingir o povo do islã em especial, enquanto ao redor deles os povos de outras religióes estarão em segurança e multiplicando-se, até que alguns grupos [de muçulmanos] se tornarão judeus, e outros grupos se tornarão cristãos".

(464) Fui informado de que Ibn Mas'ūd disse: "Chegará um tempo em que o homem será invejado por ter pouco dinheiro e poucos filhos, tal como [hoje] se inveja o homem que tem muito dinheiro e muitos filhos". Perguntaram-lhe: "Nesse dia, quais bens serão preferíveis?". Respondeu: "Boas armas e bom cavalo com o qual irás até onde ele for".

(465) Disse 'Abdulmalik:

O cego ${ }^{60}$ me contou, a partir de Al 'alā' [Bin Katīir], a partir de Anas Bin Mālik, o seguinte:

\footnotetext{
${ }^{57}$ Segundo o responsável pela edição libanesa, essa tradição está registrada no Musnad, coletânea do teólogo Aḥmad Bin Hanbal (780-855), fundador de uma das escolas jurídicas do islã sunita. Na verdade, conforme assinala J. Aguadé, “aqui parece que se reuniram dois hadițs em um”, sendo a segunda parte a registrada por Ahmad.

${ }^{58}$ Companheiro (599-676) do profeta e um dos principais transmissores de suas tradiçóes e hadịțs.

59 Tradição presente, com variação de vocabulário, em coletâneas consideradas legítimas, como a supracitada de Ahmad Bin Hanbal.

${ }^{60}$ Referência ao tradicionista Sahl Bin Bakkār Addārimī (ou Albarjamī), nascido em Basra e morto em meados do século IX d.C.
} 
Perguntei a 'Ā'iša, que Deus esteja satisfeito com ela: "Ó mãe dos crentes, conta-me sobre o terremoto". Ela respondeu: "Mas assim, ó Anas Bin Mālik, viverás triste, morrerás triste, ressuscitarás e ainda assim essa tristeza permanecerá em teu coração". Eu disse: "Conta-me, ó mãe dos crentes!". Então ela disse:

Ouvi o apóstolo de Deus, Deus o bendiga e salve, dizendo: "Quando tornarem lícito o adultério, viverem de usura, beberem vinho, tocarem instrumentos de corda, Deus descerá do seu céu e dirá à terra: “Tremei!". Se eles não se penitenciarem, Deus fará a terra os aniquilar".

'Ā'iša disse:

E a terra tremeu no tempo do apóstolo de Deus, Deus o bendiga e salve, e entáo ele subiu ao púlpito e disse: "Ó gente! Deus vos pede satisfaçóes; desagravai-o, portanto!". Perguntei: "Ó apóstolo de Deus, seremos aniquilados mesmo havendo entre nós homens pios?". Ele respondeu: "Sim, se porventura a maldade aumentar". Perguntei: "Mesmo eles rezando, apóstolo de Deus?". Respondeu: "Às vezes rezam pessoas que não valem nada". Perguntei: "Mesmo eles testemunhando que 'não há divindade senão Deus'?". O apóstolo de Deus respondeu: "A essência de testemunhar que não há divindade senão Deus é abster-se daquilo que Deus proíbe". Continuou: "Se o adorador disser 'náo há divindade senão Deus' sem se preocupar com o que falta em sua fé para o bem de sua vida mundana, Deus lhe dirá: 'Mentiste, mentiste, não és dessa fé!’”. Perguntei: “Ó apóstolo de Deus, isso acontecerá?". Ele respondeu: "Sim, e pior ainda se não ordenardes a atividade pia e não proibirdes a atividade reprovável; do contrário, surgirão grupos de canalhas, nos quais as mulheres se bastarão com mulheres, os homens com homens, e se multiplicará entre eles a maldade, e diminuirá entre eles o número de quem tenha honra, e o justo entre eles será incapaz, e o mentiroso, acreditado, e se confiará no traidor, e o honesto trairá e será mesquinho com dinheiro, ${ }^{61}$ e os ventres se tornarão estéreis, e o adultério se multiplicará, bem como os ganhos com usura e o consumo de bebidas proibidas. Quando as pessoas agirem assim, esperai o sofrimento do amanhecer até o anoitecer".

(466) Disse ['Abdulmalik]:

Alguém me contou que 'Ațā̄' Bin Yasār disse: "Entre os [sinais] da aproximação da hora [final] estão chuva sem vegetação, ressurreição de mortos, quer dizer, os adúlteros se levantarão, as vozes se elevarão nas mesquitas, surgirão bastardos e ocorrerão mortes súbitas".

(467) Abū Hurayra relatou que [o profeta] disse: "Não chegará a hora [do Juízo Final] até que o saber míngue e se multiplique o harj ${ }^{62}$ ". Perguntaram: "Ó apóstolo de Deus, o que é o harj?". Respondeu: "O assassinato".

\footnotetext{
${ }^{61}$ A tradução "e será mesquinho com dinheiro" (wa yaḍinnu bi-ddirham wa-ddinnār) supõe que o sujeito seja "o honesto", mas a oração pode ser lida como independente com verbo na voz passiva: "e haverá mesquinharia com dinheiro" (wa yudannu bi-ddirham wa-ddinār).

${ }^{62}$ Motim, tumulto.
} 


\section{Referências bliográficas}

BURCKHARDT, Titus. La civilización hispano-árabe. Madri: Alianza, 1989.

DOZY, Reinhart. Historia de los musulmanes de España. Madri: Turner, s/d. 4 volumes.

IBN ḤABĪB, 'Abd Al-Malik. Kitāb al-tārīh (La historia). Edición y Estudio por J. Aguadé. Madri: Consejo Superior de Investigaciones Científicas, 1991.

JAROUCHE, Mamede Mustafa (int. e trad.). A crônica do pseudo-Ibn Qutayba, do século IX, sobre a invasão da Península Ibérica. In: MATOS, Olgária et al. (Org.). Diálogo das civilizaçôes. São Paulo: Editora Unifesp, 2017, p. 227-241.

MAKKI, Mahmud Ali. Ensayo sobre las aportaciones orientales em la España musulmana. Madri: IEIM, 1968.

SÁNCHEZ ALBORNOZ, Claudio. En torno a los orígenes del feudalismo. Los Árabes y el régimen prefeudal carolingio. Buenos Aires: Editorial Universitaria, 1977. v. 2.

VERNET, Juan. Lo que Europa deve al Islam de España. Barcelona: El Acantilado, 1999. 